\title{
On the Road Without a Map: Why We Need an "Ethic of Road Ecology"
}

\author{
Lauren J. Moore ${ }^{1 *}$, A. Z. Andis Arietta ${ }^{2}$, Daniel T. Spencer ${ }^{3}$, Marcel P. Huijser ${ }^{4}$, \\ Bethanie L. Walder ${ }^{5}$ and Fernanda D. Abra ${ }^{6,7}$
}

${ }^{1}$ School of Animal, Rural and Environmental Sciences, Nottingham Trent University, Nottingham, United Kingdom, ${ }^{2}$ School of the Environment, Yale University, New Haven, CT, United States, ${ }^{3}$ Environmental Studies Program, University of Montana, Missoula, MT, United States, ${ }^{4}$ Western Transportation Institute, Montana State University, Bozeman, MT, United States, ${ }^{5}$ Society for Ecological Restoration, Washington, DC, United States, ${ }^{6}$ ViaFauna Estudos Ambientais, São Paulo, Brazil,

${ }^{7}$ Center for Conservation and Sustainability, Smithsonian Conservation Biology Institute, Washington, DC, United States

Over the past two decades, our knowledge of the ecological impacts of roads has increased rapidly. It is now clear that the environmental effects of transportation infrastructure are inextricable from transportation benefits to economic, social, and cultural values. Despite the necessity of optimizing these multiple values, road planners, scientists, and practitioners have no established methodology or pluralistic approach to address growing ethical complexities. We articulate five ethical issues that could be addressed by developing an ethic of road ecology in order to facilitate the identification, reasoning, and harmonization of ethical dimensions of road planning and development. This inquiry into road ecology can draw lessons from existing applied ethics, such as in ecological restoration and urban planning, to build a narrative that is informed by both science and ethics. We illustrate five ethical issues presented through case studies that elaborate on the motivations, responsibilities, and duties that should be considered in ethically and scientifically complicated road building decisions. To address these issues, we encourage the development of a code of ethics, dedicated intellectual forums, and practical guidance to assist road planners, and more broadly transportation practitioners, to resolve complex ethical quandaries systematically. We hope this perspective encourages conversation for a holistic yet pragmatic approach to this applied ethics problem, while also assisting responsible parties as they navigate difficult moral terrain.

Keywords: road ecology, ecological restoration, applied ethics, transportation, conservation, sustainable development, linear infrastructure

\section{INTRODUCTION}

Transportation infrastructure is one of the most widely distributed global anthropogenic impacts on the environment and human health. Roads can have a mutualistic relationship with human societies and are often viewed as a panacea for economic growth and social integration (Alamgir et al., 2017). The field of road ecology emerged in recognition of the multi-faceted impacts of roads on the environment to assess the extent of, and offer solutions to, the ecological problems created by transportation infrastructure (Forman et al., 2003). The field encapsulates both the science and practice of road development. It not only aims to generate the diverse theories, concepts and models that describe road interactions, but it is also central to establishing a coherent system for road planning, construction, maintenance, and management. Road ecology provides an alternative 
narrative: the potential for roads to act as liabilities, largely to the environment's integrity and human safety, while recognizing that they continue to be assets to society via access to amenities and commerce (Laurance et al., 2014).

As roads become more widespread, the ecological impacts of roads (and the avoidance, mitigation, or compensation of those impacts) are increasingly intertwined with economic, social, and cultural considerations (Vilela et al., 2020). In turn, road ecologists are forced to grapple with complex decision frameworks and ethical questions about the motivations, methods, and outcomes of their practice. Appropriate resources for this overwhelming task remain scarce, however, and the shift from an efficient but narrow engineering paradigm to holistic planning is slow. Although details vary between countries, environmental impact assessments (EIA) and, the more recently developed, strategic environmental assessments (SEA) are the principal means for assessing the impacts of development projects (Alamgir et al., 2018). Despite their strengths, these assessments most notably fall short of simultaneously achieving all ecological and socio-economic goals, often due to poor governance, vested interests, and inadequate scope. In turn, these assessments exert a relatively weak degree of influence on road planning (Ritter et al., 2017), resulting in lasting ecological and socio-economic harm.

How the impacts of roads are acknowledged, measured, and mitigated are inherently ethical decisions. As such, there is a need to build an ethical framework to consider and evaluate decisions in order to include all stakeholders in a more holistic and inclusive process and prevent monopolistic decisionmaking that uses (efficient and safe) transportation as the only priority. To fill this gap and to avoid the externalization of uncompensated environmental, social, and cultural impacts of roads, especially to nature and marginalized communities, we argue that the field of road ecology needs an applied ethic that can be tailored to different road scenarios. Topics in ecology often fall within the robust fields of environmental ethics that deal with the relationship between humans and the natural world (Minteer and Collins, 2005, 2008). The complexity of the ethical quandary surrounding road development warrants its own cross-disciplinary conversations and the identification of multiple normative commitments in road ecology. In this perspective, we outline the need for ethical justification for all actions in road development and contend that ethics can provide a critical framework for deciding if, and if so how, to pursue road development. We do not offer direct solutions to conflicts in transportation planning, but rather outline how an applied ethic could be invoked for practical reasoning and to decide on context-specific, optimal solutions.

\section{LESSONS FROM EXISTING APPLIED ETHICS}

As scientific fields mature, it is common to develop embedded subfields of applied ethics, for example the field of medical ethics or bioethics (Minteer and Collins, 2008). While we argue for a holistic, ecocentric grounding for an ethic of road ecology, an applied ethic must take a pragmatic approach to be able to engage the diversity of stakeholders impacted by road construction (Light, 2000). Fortunately, the field's moral quandaries intersect with several different forms of ethics, such as medical ethics via serious or fatal wildlife-vehicle collisions (Conover and Berryman, 2019), rights discourses, human environmental justice, and social inequality (Schell et al., 2020). An interdependence cultivated between social and road ethics could attend to equitable amelioration of harm from road effects and address long standing social justice concerns (Chamseddine and Ait Boubkr, 2020). For instance, re-routed major highways can bypass towns to aid efficiency, thereby harming local businesses that rely on passing trade. Likewise, urban planning has started to adopt explicit ethical practices to balance similar priorities to road ecology, including citizen health, sustainability, and economic development (Campbell, 2012; Basta and Moroni, 2013). A clear example of intersecting forms of ethics is the Environmental Protection Agency's Superfund program in the United States. The program is responsible for remedial action on contaminated land to protect human health, in turn overlapping with medical ethics, which simultaneously addresses environmental health and meets ecological remediation and restoration goals (Poucher et al., 2012).

\section{Broad Similarities With Ecological Restoration}

One subset of environmental ethics deals specifically with the field of ecological restoration. Ecological restoration is defined as the process of assisting the recovery of an ecosystem that has been degraded, damaged, or destroyed (Gann et al., 2019). The broad ethical principles of ecological restoration can be applied specifically to roads. Both ecological restoration and road ecology are driven by the ethical and moral responsibility of humans to reduce and reverse their impact on the environment and to safeguard nature, people and the historical legacy of an area (Almassi, 2017). Moreover, both fields are pragmatically oriented and must balance monetary cost with expected ecological output (Burgués et al., 2015). To succeed in these decisions, both require in-depth ecological knowledge of environmental dynamics and the severity of the impact of development on humans.

Both restoration and road ecology are associated with reparative and proactive action. Both also deal with the imperative to reverse human impacts (roads/development/extraction) on ecological integrity while contending with the inevitable continuation of road or other developments/extraction. Many lower- and middle-income countries are developing their transportation infrastructure as a necessary means to economic growth, reduction of poverty, and improved social well-being (Alamgir et al., 2017). This creates an opportunity to consider the development of new transportation infrastructure (as well as the reconfiguration of existing infrastructure) through the lens of road ecology. It is also an important opportunity for North America and Western Europe to learn from innovative approaches in lower income countries and vice versa (e.g., case studies \#1 and \#2, respectively, below). Road ecology in particular is underpinned by the mitigation 
hierarchy—avoidance, mitigation, and compensation. Mitigation and restoration are inherently different, with mitigation lessening the impacts of development, while restoration is intended to reverse those impacts to the maximum extent possible.

\section{Proactive Dimension}

One ethical aspect of ecological restoration that is particularly relevant to road ecology is how restoration can be used proactively as a tool for preventing ecological degradation. Specifically, because restoration cannot fully replicate or replace a degraded ecosystem, and hence should never be used to justify degradation (see ethical issue \#4 below), the first step is to prevent damage. This is similar to the first step in the mitigation hierarchy for road ecology (Cuperus et al., 1999; Young, 2000). Moreover, it is far more costly to remedy damage than to avoid it in the first place (Burgués et al., 2015). In some cases, for example, the extinction of a species or loss of sacred land, it may be impossible to reverse the damage. When considering road ecology from an ecocentric perspective, a valuable approach will question the real purpose and need of road construction. Like ecological restoration, explicating value structures will force the definition of the boundary conditions for ethical projects and provide ground for determining, when necessary, where no alternative can be justified. How damage is avoided is an ethical quandary requiring a balance of ecology and the social fabric of society (Mandle et al., 2015).

\section{Reparative Dimension}

The prevalence of roads is a major cause of the general degradation of ecosystems worldwide from human activities, including extensive habitat loss and wildlife mortality. Based on a principle of restitution between humans and nature, an ethic of ecological restoration underpins key deliberations for when, how, and where to act on damaged ecosystems (Light, 2000). Both road ecology and ecological restoration are guided by what scientific knowledge and history tell us about the ecosystems and the social and political dynamics of the area. Drawing on ecological restoration can help define the normative ground for mitigation projects around roads and help to determine mitigation goals. Although laws and assessments, such as EIAs, exist to prevent or mitigate harmful road development (Ritter et al., 2017; Alamgir et al., 2018; Mitincu et al., 2021), an ethical framework is imperative to evaluate whether all (ecological, socio-economic, cultural) negative consequences are considered and acted on in an ethical manner.

\section{Building on the Ethics of Ecological Restoration}

An ethic of ecological restoration is focused primarily on whole ecosystems and the services they provide for both humans and ecological function, whilst drawing on the intrinsic worth of nature through biocentric and ecocentric values (Hertog and Turnhout, 2018). The proponents of road ecology can build on this viewpoint to develop a pluralistic, interdisciplinary ethical framework. This should encompass concerns of human wellbeing and welfare (such as social, economic, and human health costs and benefits), animal welfare and well-being at both the species and individual level (i.e., individuals being hit by vehicles and impacts to whole species and habitats) and whole ecosystems (such as roads fragmenting landscapes and disrupting natural dynamics of resource access and migrations) (Figure 1; Alamgir et al., 2017). An interdisciplinary perspective at the intersection between anthropogenic and ecological milieus is imperative and steadily gaining traction (Schell et al., 2020). The responses of ecosystems and communities toward roads around the world are dependent on the habitats, people, and road characteristics involved. Whilst the path to sustainable road development will be different in each road scenario, an ethic of road ecology can form a solid framework to critically consider how potential solutions are generated and evaluated. This, in turn, could help to build guidelines for best practice.

\section{ETHICAL ISSUES IN ROAD ECOLOGY}

Ethical issue \#1-To what extent do ecological impacts intersect with and measure against other value structures?

In a world of limited resources, addressing manifold values will inevitably require the balancing of trade-offs among competing goals. For instance, in road planning, there is a perennial contention to jointly maximize efficiency and safety while minimizing costs. Other issues (e.g., impact to local communities and ecological conditions) receive much less consideration because those costs are typically externalized in economic analyses or road proponents are unaware of ecological risks due to a lack of evidence-based decision making in EIAs and SEAs (Alamgir et al., 2018; Mitincu et al., 2021). Conservation and restoration planning frameworks have been developed to jointly evaluate biodiversity and societal or economic benefits (Chan et al., 2006; Halpern et al., 2013). The Society for Ecological Restoration (SER) has developed both an ecological recovery wheel and a paired social benefits wheel (Gann et al., 2019) which, if applied to road ecology, could be expanded to simultaneously consider social, human well-being, ecological, and transportation goals. At present, a lack of social scientist inclusion in road ecology hinders this motivation. Although limited to extractive sectors to date, gaining a Social License to Operate (SLO) can help weigh and address a wider scope of ecological and community values that might otherwise be ignored by the road building entity. A SLO refers to the process of engaging the community and all stakeholders to ensure their voices are heard and respected as part of the road planning and development process in a way that addresses multiple issues (Owen and Kemp, 2018). While building the SLO requires time and monetary investment, it may save costs over the long term by securing support and reducing potentially costly opposition to the project. Although challenging, expanding the purview of planners to encompass all these values and more in an ethic of road ecology should result in transportation infrastructure development providing greater overall benefits. Failure to do so can stall the project (see case study \#1), inflate the monetary cost, and/or result in suboptimal or even damaging solutions.

Recommended Solution: Prioritize a truly participatory process, involving knowledge sharing amongst ecologists, social scientists, and practitioners, to engage stakeholders in an equal and equitable manner. It should be based on multi-criterion, 


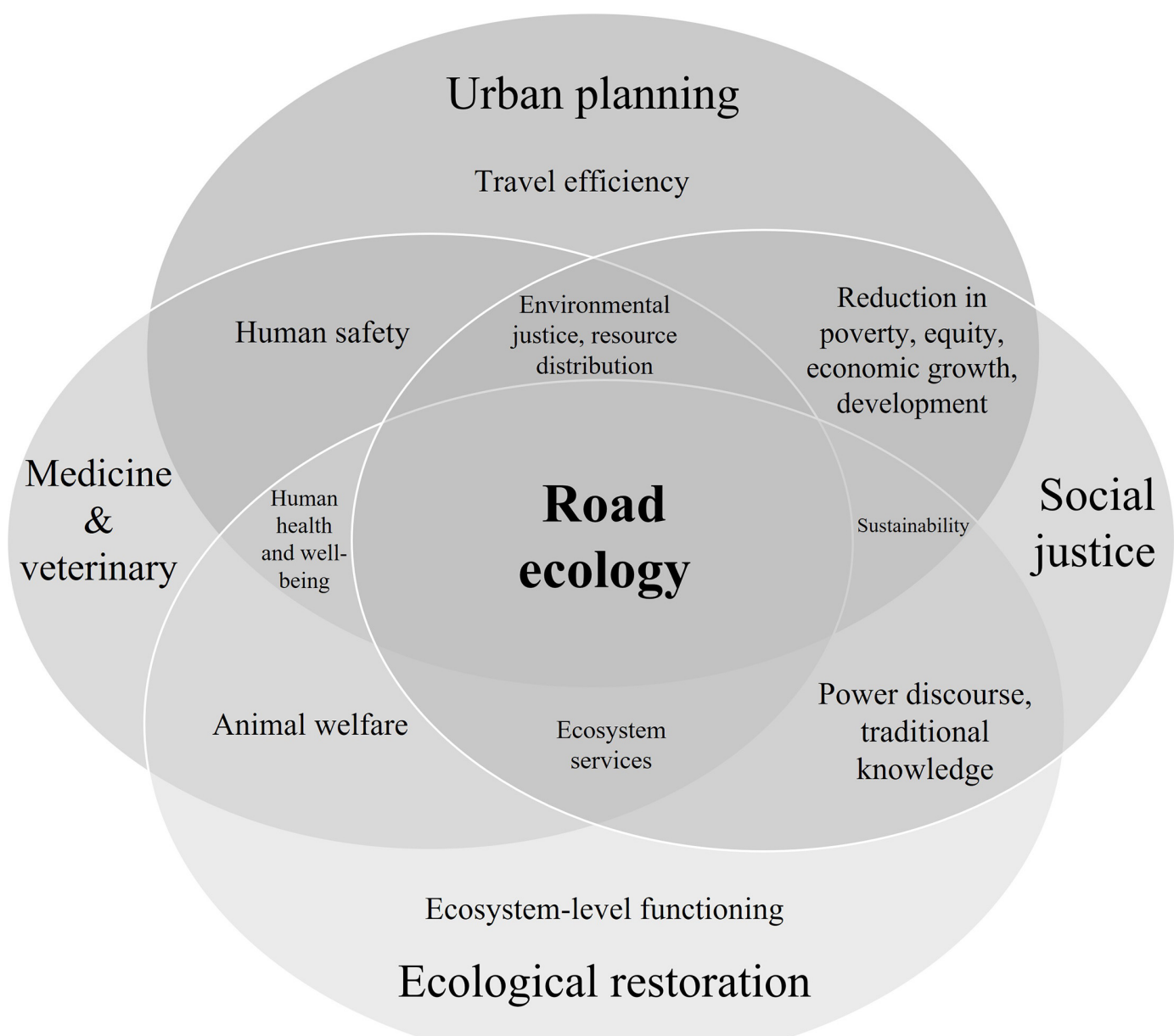

FIGURE 1 | The intersection of the ethical considerations of road ecology with those of several other fields.

evidence-based decision-making to create a Social License to Operate that protects social, human health and well-being, and ecological interests without relying exclusively on legal requirements. The process must be flexible enough to obtain the optimal outcome regardless of the specific situation.

\section{Case Study \#1}

In the late 1980s, planning began to redesign a section of highway US93 - a major corridor connecting Missoula to Glacier National Park in Montana, United States-through the Flathead Indian Reservation. The original road redesign project was mostly based on a "traditional engineering" approach that did not adequately address the social, cultural, historical, and ecological concerns of the Confederated Salish and Kootenai Tribes (CSKT). Since the CSKT are a sovereign nation with government-to-government negotiation rights with the state and federal government, their position forced a more balanced approach to the road redesign project. After approximately 10 years, the Federal, State and Tribal governments finally agreed on a "Context Sensitive" design process. The three governments agreed to reconstruct US93 North based on the idea that "the road is a visitor and that it should respond to and be respectful of the land and the Spirit of the Place." The "guiding philosophy" for the highway reconstruction was to "protect cultural, aesthetic, recreational, and natural resources located along the highway corridor and to communicate the respect and value that is commonly held for these resources pursuant to traditional ways of the Tribes" (Federal Highway Administration (FHWA), 2000; US 93 Design Discussions Project Committee, 2000). The measures along the 56 mile $(90 \mathrm{~km})$ long road section included a reduction of the size of the road's footprint, the installation of wildlife crossing structures at 39 locations, and approximately 8.71 miles $(14.01 \mathrm{~km})$ of wildlife exclusion fences on both sides (Becker and Basting, 2010; Kroll, 2015).

The story of US93 south of Missoula is a parallel story with a very different outcome. The local community lobbied for similar measures as on the Reservation, but because they lacked the legal power of the CSKT, the road received far less social and environmental consideration (Montana Department of Transportation, 2008).

Ethical issue \#2-How much negative impact on the environment, communities and economies can we allow before we determine that there is no ethical way to build a road? 
Adopting an ethic of road ecology that values competing goals necessarily creates boundary conditions for ethical decisions-that is, there will be some projects for which no satisfactory solutions exist that sufficiently address minimum goals. Thus, an ethic of road ecology should provide not only a framework for evaluating road projects but guidance in determining when a road is unacceptable to be built at all (Figure 2). For example, the United Kingdom's National Planning Policy Framework outlines criteria where planning permission is refused on the grounds of biodiversity protection at a project and landscape scale (Ministry of Housing, 2021). This may create a paradigm shift from current approaches where road ecology often comes into play only after a road has been approved, regardless of whether these considerations have been fully incorporated into any legally required environmental analysis. However, addressing this presupposition earlier in the planning process can avoid costly litigation, as in case study \#2. Although many countries require environmental impact assessments, these steps typically only consider a small subset of the total ethical ramifications of road projects.

Recommended Solution: Clearly articulate the attributes, boundaries and context that road ecologists and transportation planners can use, early in the planning process, to assess whether a road's impacts are so great that they cannot be mitigated.

Ethical Issue \#3-How do we take a comprehensive and ecocentric approach to addressing road impacts?

In much the same way that ecological impacts of roads extend far beyond the proximate roadway (i.e., the "road effect zone"), the ethical ramifications of road projects are not limited to the road corridor itself. This raises the question of how distally and cumulatively should an ethical framework extend (Jaeger, 2015)? For instance, are road ecologists to consider cumulative impacts of all associated road development when evaluating a specific project? Or, similarly, should road ecologists consider the secondary and tertiary effects from a road project? SER's 7th principle for ecological restoration argues that landscapelevel planning can help reduce "environmental leakage" or displacement of impacts from one mitigated or restored site to another (Gann et al., 2019). This same premise is relevant in road ecology. By planning at the landscape scale, road ecologists can create more integrated and holistic benefits. Additional lessons can be learned from efforts to create multi-functional landscapes that better accommodate both nature and people. For instance, both paved and unpaved roads allow people to enter new frontiers, often leading to a contagion of deforestation, mining, and poaching. Should poached animals be included in the mortality impacts of roads? Are transportation planners accountable for potential reductions in availability or exploitation of bushmeat supplies on which indigenous groups depend for survival and social cohesion (Espinosa et al., 2014)? The inadequate consideration of risks in road infrastructure planning is a well-cited flaw of EIAs. Assessments often focus on potential local impacts within a narrow spatial and temporal scale and therefore fail to adequately assess the impact of development on the whole landscape (Ritter et al., 2017; Alamgir et al., 2018). The hydrologic impacts of roads, especially dirt roads, are not always considered in road planning, design, and environmental analyses. Climate change appears to be increasing the intensity of storms in many areas, and this can lead to increased social and ecological impacts due to, for example, road failures and associated interruptions of transportation access for people; road triggered landslides and associated water quality impacts if those landslides intersect with rivers or streams; and increased sediment and chemical (from road surface) delivery to rivers and streams with associated impacts to fisheries, human drinking water supplies, reservoir lifespans (Luce, 2002; Meyer et al., 2014; Alamgir et al., 2018).

Recommended Solution: Assess individual road projects in the context of the overall landscape, and, wherever possible, incorporate landscape- and watershed-level planning and cumulative effects into the transportation planning process.

\section{Case Study \#2}

In the 1980s, linear transportation infrastructure, including roads, railroads, and canals, was increasingly recognized as a substantial cause of habitat fragmentation and unnatural wildlife mortality in The Netherlands. In response to this, a national nature policy plan introduced the concept "ecological main structure" ("Ecologische Hoofdstructuur" or "EHS”) (Ministerie van Landbouw, Natuur en Voedselkwaliteit, 1990). It explicitly recognized that people, goods and nature simultaneously needed not only a place in the landscape but also corridors for connectivity. Space is extremely scarce in The Netherlands and there is therefore a high level of coordination between national, provincial, and local government to designate space responsibly. Quantitative ecological goals were formulated for different parts of the EHS and assessments showed what was needed to accomplish those goals.

In 2004, a multi-year habitat defragmentation program (Meerjarenprogramma Ontsnippering, MJPO) was initiated to assist the realization of the EHS (later renamed National Ecological Network or "NEN," Natuurnetwerk Nederland" or "NNN" in 2013) and the responsibility of the program transferred from the national government to the provinces in 2014. The goal is to realize a total area of the NEN (core areas and corridors combined) of approximately 750,000 hectares of land by 2027 , which represents about $22 \%$ of the total land surface of the country (Kampf and Stavast, 2005; Vodde et al., 2005). By 2018, 166 of the 176 initially identified problem locations along main roads, railroads and canals had been fully or partially addressed (MJPO, 2020). Within the framework of the program, different types of crossing structures were constructed: 39 ecoducts or overpasses for exclusive wildlife use, 45 bridges or viaducts with mixed wildlife and human use, 22 large mammal underpasses, 177 culverts for small animal species, 130 culverts and bridges that were made suitable for wildlife passage, 3 arboreal crossing structures, 60 exits for wildlife along canals with steep banks, 33 fence projects and other measures that help direct wildlife to safe crossing opportunities (MJPO, 2018, 2020). Connecting small tracts of natural habitat via these many crossing structures has created a large, integrated, and permeable network of habitat that can support larger populations of more species. The return of wolves to The Netherlands from 2015 onward, after about 150 years of absence, and the subsequent first reported breeding of wild wolves in The Netherlands in 2019 (Wolven in Nederland, 
2021), was likely partially aided by the mitigation measures along roads that reduce road mortality and connect the remaining natural habitat.

Ethical Issue \#4-How to avoid inflicting ecological harm because of a set of objectives that is too narrow?

Reducing collisions with large wild mammals benefits human safety, reduces injuries and unnatural mortality for wildlife, and also reduces costs associated with vehicle repair, human injuries, and human fatalities. Wildlife fences are the most robust and economical way to achieve these objectives (Huijser et al., 2009). As a stand-alone mitigation measure, wildlife fences can be beneficial for species that rarely or never succeed in their attempts to cross the road or for species whose population is declining partially because of high traffic mortality (Jaeger and Fahrig, 2004). However, fences as a stand-alone measure are not recommended for species whose population size is stable or increasing, or if the animals need access to resources on both sides of the road (Jaeger and Fahrig, 2004). In addition, even if a population's survival probability in the area is not deemed a concern, the ecological integrity of an ecosystem may be affected by wildlife fences, such as through the loss of the ability to seasonally migrate. Furthermore, existing or anticipated movements of rare or endangered species that have very low population density should not be blocked by a wildlife fence that aims to be beneficial to both people and wildlife. Since real-world landscapes host a wide variety of species, wildlife fences should almost never be implemented without (at least not over the long term) also providing safe crossing opportunities for a wide array of species or species groups.

Recommended Solution: Highway projects that relate to wildlife, or that affect wildlife, should typically include multifaceted ecological objectives that addresses multiple road effects. Specifically, if the objective is to reduce wildlife-vehicle collisions through wildlife fences, there should be an associated objective to maintain or improve wildlife connectivity.

\section{Case Study \#3}

An $8 \mathrm{ft}(2.4 \mathrm{~m})$ tall wildlife fence was installed along a 33-mile-long $(53 \mathrm{~km})$ section of I-70 (mile reference post 140-173) between Gypsum and Avon in Colorado (United States) in 2010 (Colorado Department of Transportation, 2011). The objective was to reduce the number of collisions with elk and deer. The fences were connected to existing underpasses that were built for other purposes (e.g., water, vehicles on dirt and paved roads, trains), but there were no designated wildlife underpasses or overpasses (Singer et al., 2011). The location, type, and dimensions of the existing crossing structures (mostly box culverts and bridges) are either not at all, or only marginally, suitable for wildlife species that may need or want to access the other side of the fenced I-70 corridor, illustrating that wildlife connectivity was not a major concern or objective. For large mammals that become trapped in the fenced road corridor, escape ramps (58 in total) allow them to return to the safe side of the fence. The fenced road section was later expanded to cover a total of approximately 40 miles of I-70 between Dotsero and Eagle Vail with the potential to cause further habitat fragmentation (Colorado Department of Transportation, 2017). In general, the need for wildlife connectivity relates not only to animals that live in the immediate vicinity of the road permanently, but also to animals that have seasonal migration, and animals that mostly live far away from the road but that may disperse through the area occasionally. Another project in Colorado, along State Highway 9 between Kremmling and Green Mountain Reservoir, specifically included objectives related to both reducing wildlifevehicle collisions and maintaining or improving connectivity for wildlife. Here, the measures included a wildlife fence over a road length of 10.3 miles. In addition, this road section was equipped with 2 wildlife overpasses and 5 wildlife underpasses, 29 wildlife guards, and 61 escape ramps (Kintsch et al., 2021). Monitoring documented that seventeen wildlife species successfully used the crossing structures, whilst the wildlife crossings and fencing mitigation helped decrease wildlife-vehicle collisions by $90 \%$ relative to preconstruction levels (Kintsch et al., 2021).

Ethical Issue \#5-Could road mitigation measures be used as a justification to rationalize more roads or larger transportation impacts?

Concern for the negative impacts of roads has resulted in the development of a suite of road mitigation measures to reduce the identified impacts. This includes wildlife warning signs and overpasses to reduce animal-vehicle collisions and/or improve habitat connectivity, and boundary noise and vegetation barriers to reduce noise and air pollution, and control water runoff (Forman et al., 2003). A tendency to rely on the potential of road mitigation may interfere with a clear evaluation of the damaging implications, thus creating an obstacle to safeguarding the original value and integrity of unimpacted natural areas. This reflects a salient ethical issue also seen in ecological restoration. Early in the development of ecological restoration, environmental philosophers Elliot (1982) and Katz (1992) argued that restoration would be used to rationalize the initial destruction of nature, under the logic of restoring the original value of nature (both actual and functional) after extracting resources for economic value. Ironically, the promise of future restoration could then lead to the further degradation of nature. Light (2000) termed this form of restoration "malicious restoration," but argued that restoration can also be a morally required action of ecological restitution, taken to remedy past harms done to nature. Key to both positions is recognizing the a priori value of non-degraded nature; restoration is only ethically justified when it seeks to restore ecological integrity to already degraded ecosystems. Similarly, an ethic of road ecology starts from the a priori value of non-degraded nature and ecosystems, so compelling moral reasons must be given to degrade nature through road construction.

Recommended Solution: Being transparent about the moral values of all parties at stake in road assessment processes and being upfront about conflicts in values prevents the field from inadvertently becoming a tool of greenwashing, i.e., conveying a false impression or providing misleading information that road development is more sustainable that it actually is.

\section{Case Study \#4}

São Paulo is the biggest city in South America, where both urban mobility and industrial transportation are significant challenges. Construction of the Rodoanel Mário Covas Ring Road was initiated to relieve the intense truck traffic to São Paulo in 
1998. The state of São Paulo has been leading innovations in Latin America for the management of the road network. Since 1998, the state has initiated a road concession program to improve road networks that meet driver safety and other engineering standards and improve their environmental and social sustainability [Agência de Transporte do Estado de São Paulo (ARTESP), 2021]. All toll road companies are obligated to check the entire length of their highways at least every $3 \mathrm{~h}$ looking to register and remove animal carcasses from the road (Abra et al., 2021). For each carcass, maintenance personnel are required to collect the date, time, location, common species name, and the status and destination of the animal carcass (e.g., whether the carcass of the animal was sent to a specific institution or if it was buried). A unique and collaborative approach is taken for wildlife rescue efforts that involved NGOs, rehabilitation centers and toll companies. The latter is not only responsible for collecting roadkill data, but also for transporting injured animals to vets.

Construction on the northern and final stretch of the ring road, North Ring Road, started in 2013. The road is $44 \mathrm{~km}$ long and experienced significant environmental challenges from planning through to construction. For example, the initial design plan proposed the construction of Rodoanel Norte through the south of Cantareira State Park (CSP). This park is one of the biggest urban forests in the world and a UNESCO-designated green belt biosphere reserve. While the location of the road was modified to protect municipal water sources, it still bisects a portion of CSP. Construction on North Ring Road includes five fauna programs: (I) wildlife monitoring, (II) wildlife rescue, (III) domestic animal rescue, (IV) howler monkey monitoring (Allouata clamitans-an endangered species) and (V) implementation of mitigation measures to reduce wildlifevehicle collisions and increase connectivity. For example, the design includes seven road tunnels totaling $6.2 \mathrm{~km}$ and viaducts totaling $7.5 \mathrm{~km}$. The $44 \mathrm{~km}$ construction site was divided into six areas, each of which has its own veterinarian, field biologist, and veterinary hospital (Calixter et al., 2016). Owing to the success of the initial rescue program, few animals required veterinarian treatment and most rescued animals were translocated to undisturbed, high-quality habitat patches located nearby. The North Ring Road is an innovative and outstanding project with the potential to act as a model for projects in areas with high biodiversity.

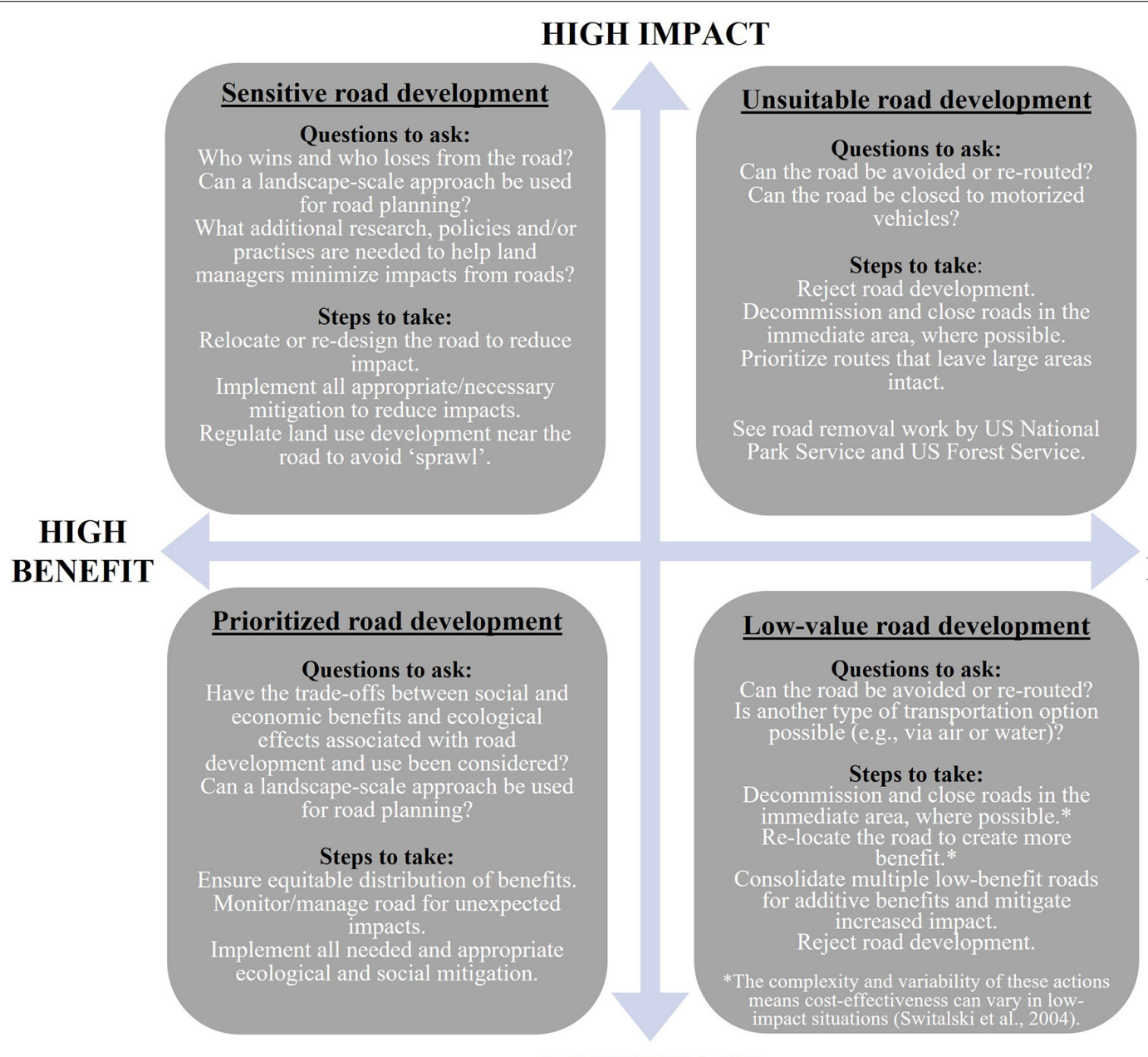

\section{LOW IMPACT}

FIGURE 2 | Conceptual plan to portray a range of scenarios in road development, key questions to ask, and recommended steps to take in each scenario. 


\section{FUTURE DIRECTIONS FOR AN ETHIC OF ROAD ECOLOGY}

The distinct area of practical ethics surrounding road development requires further conceptual and institutional work. We propose some steps toward ethical clarification and practical decision-making in road development:

a. Inclusive and dedicated conversation venues (e.g., symposiums, presentations, and articles) to contribute to a broader understanding of the ethical context of road development for ecologists, social scientists and road planners, and to aid ethical literacy to pragmatically deal with complex issues.

b. Case library and discussion platform (e.g., through journals and dedicated sessions) as a tool for all parties to share problems and solutions, and to improve critical thinking and ethical reasoning.

c. A code of ethics to express multivariate values and provide a mechanism for assessing responsible conduct and accountability in road development.

d. A set of principles developed collaboratively to characterize and guide road development under different scenarios.

e. Guidance for transportation practitioners more broadly by applying some of the ethical questions raised here to transportation planning and including this in best-practice guidelines.

\section{CONCLUSION}

Transportation infrastructure can reasonably be considered a primary driver of ecological change across the globe. Growing populations and economies worldwide create a powerful incentive for road development, expansion, and upgrades. Road ecology can benefit by recognizing the nexus of existing applied ethics tools and adapting those for specific ethical issues in transportation. Derived most notably from ecological restoration

\section{REFERENCES}

Abra, F. D., Huijser, M. P., Magioli, M., Bovo, A. A. A., and de Barros, K. M. P. M. (2021). An estimate of wild mammal roadkill in são paulo state, Brazil. Heliyon 7:e06015. doi: 10.1016/j.heliyon.2021.e06015

Agência de Transporte do Estado de São Paulo [ARTESP] (2021). Concessions Program. Available online at: http://www.artesp.sp.gov.br (accessed August 15, 2021).

Alamgir, M., Campbell, M. J., Sloan, S., Goosem, M., Clements, G. R., Mahmoud, M. I., et al. (2017). Economic, socio-political and environmental risks of road development in the tropics. Curr. Biol. 27:20. doi: 10.1016/j.cub.2017.0 8.067

Alamgir, M., Campbell, M. J., Sloan, S., Phin, W. E., and Laurance, W. F. (2018). Road risks and environmental impact assessments in Malaysian road infrastructure projects. Jurutera 13-16.

Almassi, B. (2017). Ecological restorations as practices of moral repair. Ethics Environ. 22:1. doi: 10.2979/ethicsenviro.22.1.02

Basta, C., and Moroni, S. (2013). Ethics, Design and Planning of the Built Environment. Berlin: Springer. ethics and guiding principles, road ecology should be framed by the question of whether a road is needed or justified and, if so, how to do so in a transparent, inclusive, and equitable manner that achieves optimal ecological, social, and human wellbeing outcomes. Enlightened and inclusive ethical accounting in road development is contingent on open discussions across disciplines. A context-specific, symbiotic relationship with culture, social justice, economics, and ecology is needed to identify and appraise how far our ethical responsibilities extend and to certify a road as desirable (Jaeger, 2015). Such discussions would naturally extend to similar ethical decision-making in transportation planning. By having these conversations, developing a case study library and a code of ethics, it is feasible to embed the right questions and value assessments into a principled and ethical approach to current and future road development worldwide.

\section{DATA AVAILABILITY STATEMENT}

The original contributions presented in the study are included in the article/supplementary material, further inquiries can be directed to the corresponding author/s.

\section{AUTHOR CONTRIBUTIONS}

LM and AA prepared the original manuscript draft. DS, MH, BW, and FA wrote additional sections of the text. LM, AA, DS, MH, and $\mathrm{BW}$ reviewed and edited the manuscript. All authors have read and approved the manuscript.

\section{ACKNOWLEDGMENTS}

We would like to sincerely thank Dave Havlick for valuable discussions and comments on an early version of the manuscript.

Becker, D. M., and Basting, P. (2010). "“Reconstruction of U.S. Highway 93: Collaboration between three governments," in Safe Passages: Highways, Wildlife, and Habitat Connectivity, eds J. P. Beckmann, A. P. Clevenger, M. P. Huijser, and J. A. Hilty (Washington, DC: Island Press), 173-187.

Burgués, I., Brunner, A., Barr, R., Malky, A., Behm Mazosera, A., and Reid, J. (2015). Making the Economic Case to Promote Avoidance in Infrastructure Development. Impact Assessment in the Digital Era: 35th Annual Conference of the International Association for Impact Assessment (Florence). Available online at: www.iaia.org (accessed June 23, 2021).

Calixter, A. L., Ignacia Arrasate, M., Georgoulias, A., Taddia, A., Ramirez, M. C., Watkins, G., et al. (2016). Mário Covas Rodoanel Project: Northern Section, Brazil. Available online at: https://publications.iadb.org/publications/english/ document/Mário-Covas-Rodoanel-Project-Northern-Section-Brazil.pdf (accessed July 29, 2021)

Campbell, H. (2012). 'Planning Ethics' and rediscovering the idea of planning. Plan. Theory 11:4. doi: 10.1177/1473095212442159

Chamseddine, Z., and Ait Boubkr, A. (2020). exploring the place of social impacts in urban transport planning: the case of casablanca city. Urban Plan. Transp. Res. 8:1. doi: 10.1080/21650020.2020.1752793 
Chan, K. M. A., Shaw, M. R., Cameron, D. R., Underwood, E. C., and Daily, G. C. (2006). Conservation planning for ecosystem services. PLoS Biol. 4:e379. doi: 10.1371/JOURNAL.PBIO.0040379

Colorado Department of Transportation (2011). Wildlife on the Move! Available online at: https://www.codot.gov/news/2011news/10-2011/wildlife- on-themove (accessed August 5, 2021).

Colorado Department of Transportation (2017). Installation of New Wildlife Fence Begins Along I-70. Available online at: https://www.codot.gov/news/2017news/march/installation- of-new-wildlife-fence-begins-along-i-70 (accessed August 5, 2021).

Conover, M. R., and Berryman, J. H. (2019). Numbers of human fatalities, injuries, and illnesses in the United States due to wildlife. Hum. Wildl. Interact. 13, 264-276. doi: 10.1580/06-weme-or-014r1.1

Cuperus, R., Canters, K. J., Udo De Haes, H. A., and Friedman, D. S. (1999). Guidelines for ecological compensation associated with highways. Biol. Conserv. 90:1. doi: 10.1016/S0006-3207(99)00007-5

Elliot, R. (1982). Faking nature. Inquiry 25:1. doi: 10.1080/0020017482086 01955

Espinosa, S., Branch, L. C., and Cueva, R. (2014). Road development and the geography of hunting by an amazonian indigenous group: consequences for wildlife conservation. PLoS One 9:e114916. doi: 10.1371/journal.pone.01 14916

Federal Highway Administration (FHWA) (2000). Memorandum of Agreement. US 93 Evaro to Polson. Available online at: http://www.mdt.mt.gov/pubinvolve/ polsoncorridorstudy/docs/moa.pdf. (accessed August 22, 2021).

Forman, R., Sperling, D., Bissonette, J., Clevenger, A., and Cutshall, C. (2003). Road Ecology: Science and Solutions. Washington, DC: Island Press.

Gann, G. D., McDonald, T., Walder, B., Aronson, J., Nelson, C. R., Jonson, J., et al. (2019). International principles and standards for the practice of ecological restoration. Second edition. Restor. Ecol. 27:1. doi: 10.1111/REC.13035

Halpern, B. S., Klein, C. J., Brown, C. J., Beger, M., Grantham, H. S., Mangubhai, S., et al. (2013). Achieving the triple bottom line in the face of inherent trade-offs among social equity, economic return, and conservation. Proc. Natl. Acad. Sci. U.S.A. 110:15. doi: 10.1073/pnas.1217689110

Hertog, I. M., and Turnhout, E. (2018). Ideals and pragmatism in the justification of ecological restoration. Restor. Ecol. 26:6. doi: 10.1111/REC.12680

Huijser, M. P., Duffield, J. W., Clevenger, A. P., Ament, R. J., and McGowen, P. T. (2009). Cost-Benefit analyses of mitigation measures aimed at reducing collisions with large ungulates in the united states and canada: a decision support tool. Ecol. Soc. 14:2. doi: 10.5751/ES-03000- 140215

Jaeger, J. A. G. (2015). "Improving environmental impact assessment and road planning at the landscape scale," in Handbook of Road Ecology, eds R. van der Ree, D. J. Smith, and C. Grilo (West Sussex: John Wiley \& Sons), 32-42. doi: 10.1002/9781118568170.ch5

Jaeger, J. A. G., and Fahrig, L. (2004). Effects of Road Fencing on Population Persistence. Conserv. Biol. 18, 1651-1657.

Kampf, H., and Stavast, F. (2005). Report on the Implementation of the PanEuropean Ecological Network, The Netherlands, 2005. Available online at: https: //edepot.wur.nl/118375 (accessed August 7, 2021).

Katz, E. (1992). The big lie: human restoration of nature. Res. Philos. Technol. 12, 93-107. doi: 10.1080/15548627.2015.1100356

Kintsch, J., Cramer, P., Singer, P., and Cowardin, M. (2021). State Highway 9 Wildlife Crossings Mitigation Monitoring, Denver. Available online at: https:/www.codot.gov/programs/research/pdfs/2021-research-reports/statehighway-9-wildlife-mitigation-monitoring/cdot-2021-01.pdf (accessed August 5, 2021)

Kroll, G. (2015). An environmental history of roadkill: road ecology and the making of the permeable highway. Environ. Hist. Durh. N. C. 20:1. doi: 10. 1093/envhis/emu129

Laurance, W. F., Clements, G. R., Sloan, S., O'Connell, C. S., Mueller, N. D., Goosem, M., et al. (2014). A global strategy for road building. Nature 513, 229-232. doi: 10.1038/nature13717

Light, A. (2000). "Ecological restoration and the culture of nature-a pragmatic perspective," in Restoring Nature, eds P. H. Gobster and R. B. Hull (Washington, DC: Island Press). doi: 10.1098/rstb.2017.0434

Luce, C. H. (2002). Hydrological processes and pathways affected by forest roads: what do we still need to learn? Hydrol. Process. 16:1.
Mandle, L., Tallis, H., Sotomayor, L., and Vogl, A. L. (2015). Who loses? Tracking ecosystem service redistribution from road development and mitigation in the peruvian amazon. Front. Ecol. Environ. 13:6. doi: 10.1890/1 40337

Meyer, M., Flood, M., Keller, J., McVoy, G., Dorney, C., Leonard, K., et al. (2014). Strategic Issues Facing Transportation. Volume 2: Climate Change, Extreme Weather Events, and the Highway System: Practitioner's Guide and Research Report. Available online at: https://web.law.columbia.edu/sites/ default/files/microsites/climate-change/nchrp_report_750.pdf (accessed October 18, 2021).

Ministerie van Landbouw, Natuur en Voedselkwaliteit (1990). Natuurbeleidsplan. Available online at: https://archive.org/details/naturepolicyplan/page/n13/ mode/2up. (accessed August 2, 2021).

Ministry of Housing (2021). National Planning Policy Framework. London, UK. Available online at: https://assets.publishing.service.gov.uk/government/ uploads/system/uploads/attachment_data/file/1005759/NPPF_July_2021.pdf. (accessed August 7, 2021).

Minteer, B. A., and Collins, J. P. (2005). Why we need an "ecological ethics". Front. Ecol. Environ. 3:6. doi: 10.2307/3868567

Minteer, B. A., and Collins, J. P. (2008). From environmental to ecological ethics: toward a practical ethics for ecologists and conservationists. Sci. Eng. Ethics 14:4. doi: 10.1007/s11948-008-9087-0

Mitincu, C. G., Ioja, I. C., Hossu, C. A., Artmann, M., Nita, A., and Nita, M. R. (2021). Licensing sustainability related aspects in strategic environmental assessment. evidence from romania's urban areas. Land Use Policy 108:105572. doi: 10.1016/j.landusepol.2021.105572

MJPO (2018). Eindfilm. Available online at: https://www.youtube.com/channel/ UCTy2o6zUlufVAhcRURxWYiw. (accessed July 3, 2021)

MJPO (2020). Natuur Verbonden. Meer Leefruimte Voor Dieren in Nederland. Resultaten meerjarenprogramma ontsnippering. Available online at: https: //www.mjpo.nl/now/c_documents/EindboekMJPO2020.pdf. (accessed July 3, 2021).

Montana Department of Transportation (2008). US 93 Corridor Study. Missoula. Available online at: https://www.mdt.mt.gov/pubinvolve/us93corridor/ documents.shtml (accessed August 5, 2021).

Owen, J., and Kemp, D. (2018). Mine closure and social performance: an industry discussion paper. Centre for Social Responsibility in Mining, Sustainable Minerals Institute, The University of Queensland: Brisbane. Available online at: https://www.csrm.uq.edu.au/publications/mine-closure-and-socialperformance (accessed October 20, 2021).

Poucher, S. L., Tracey, G. A., Johnson, M. S., and Haines, L. B. (2012) Review of ecological-based risk management approaches used at five army superfund sites. Integr. Environ. Assess. Manag. 8:2. doi: 10.1002/ieam. 1249

Ritter, C. D., McCrate, G., Nilsson, R. H., Fearnside, P. M., Palme, U., and Antonelli, A. (2017). Environmental impact assessment in brazilian amazonia: challenges and prospects to assess biodiversity. Biol. Conserv. 206, 161-168. doi: 10.1016/ j.biocon.2016.12.031

Schell, C. J., Dyson, K., Fuentes, T. L., Roches, S., Des Harris, N. C., Miller, D. S., et al. (2020). The ecological and evolutionary consequences of systemic racism in urban environments. Science 369:6510. doi: 10.1126/SCIENCE.AA Y4497

Singer, P., Huyett, A., and Kintsch, J. (2011). I-70 Eco-Logical Monitoring and I-70 Wildlife Watch Report. Available online at: http://www.environment.fhwa.dot. gov/ecological/ (accessed August 5, 2021).

Switalski, T. A., Bissonette, J. A., DeLuca, T. H., Luce, C. H., and Madej, M. A. (2004). Benefits and impacts of road removal. Front. Ecol. Environ. 2:1.

US 93 Design Discussions Project Committee (2000). Landscape architect design \& alignment concepts. Available online at: https://westerntransportationinstitute. org/wp-content/uploads/2019/03/US-93-Lanscape-Architect-Design-andAlignment-Concepts-December-20-2000.pdf (accessed September 2, 2021).

Vilela, T., Harb, A. M., Bruner, A., Laísa, V., Arruda, S., Ribeiro, V., et al. (2020). A better Amazon road network for people and the environment. PNAS 117:13. doi: 10.1073/pnas.1910853117

Vodde, F., Wijdeven, S. M. J., and Mohren, G. M. J. (2005). "Country reportThe Netherlands," in COST Action E27-Protected Forest Areas in EuropeAnalysis and Harmonisation (PROFOR): Reports of Signatory States, eds J. 
Latham, G. Frank, O. Fahy, K. Kirby, H. Miller, and R. Stiven (Vienna: BFW), 243-261.

Wolven in Nederland (2021). Wolven in Nederland. Available online at: https: //www.wolveninnederland.nl/nieuws (accessed August 5, 2021).

Young, T. P. (2000). Restoration ecology and conservation biology. Biol. Conserv. 92:1. doi: 10.1016/S0006-3207(99)00057-9

Conflict of Interest: FA was employed by the company ViaFauna Estudos Ambientais.

The remaining authors declare that the research was conducted in the absence of any commercial or financial relationships that could be construed as a potential conflict of interest.
Publisher's Note: All claims expressed in this article are solely those of the authors and do not necessarily represent those of their affiliated organizations, or those of the publisher, the editors and the reviewers. Any product that may be evaluated in this article, or claim that may be made by its manufacturer, is not guaranteed or endorsed by the publisher.

Copyright (c) 2021 Moore, Arietta, Spencer, Huijser, Walder and Abra. This is an open-access article distributed under the terms of the Creative Commons Attribution License (CC BY). The use, distribution or reproduction in other forums is permitted, provided the original author(s) and the copyright owner(s) are credited and that the original publication in this journal is cited, in accordance with accepted academic practice. No use, distribution or reproduction is permitted which does not comply with these terms. 